\title{
PEMBELAJARAN PEDAGOGIK SPIRITUAL
}

\author{
Umi Salamah, Aam Abdussalam, Makhmud SyafeI, Endis Firdaus \\ Universitas Pendidikan Indonesia (UPI) Bandung Jawa Barat, Indonesia \\ Email: umisalamah83@upi.edu, aam86@upi.edu,S.makhmud55@gmail.com, \\ endisf@upi.edu
}

\begin{abstract}
Abstrak
Tujuan penulisan ini adalah untuk mengetahui bagaimana proses pembelajaran dan evaluasi itu berlangsung selama proses belajar mengajar yang diselenggarakan oleh pendidik, dan peserta didik tidak hanya sebagai objek pendidikan tetapi juga sebagai subjek. Tulisan ini menggunakan pendekatan kualitatif dan metode studi literatur. Dalam dunia pendidikan, pembelajaran dapat memberdayakan peserta didik menjadi manusia yang mandiri dan mampu merebut berbagai peluang dalam kehidupan saat ini yang sangat kompetitif. Hal ini jika dikaitkan dengan pedagogik spiritual, hasil yang diharapkan sebagai bahan evaluasi oleh seorang pendidik adalah ketika peserta didiknya menanamkan sifat-sifat ketauhidan didalam dirinya sehingga menjadi khalifah Allah yang amanah di muka bumi dengan mengembangkan segala potensi yang ada dalam dirinya tersebut. Keberhasilan dari proses pembelajaran dan evaluasi tersebut, tidak akan terlepas dari komponenkomponen penunjang di dunia pendidikan yakni komponen visi, misi, tujuan, kurikulum, proses belajar mengajar, pendidik, peserta didik, manajemen pengelolaan, pembiayaan, sarana prasarana, lingkungan, jaringan komunikasi dan kerja sama, serta evaluasi pendidikan dan dasar strategi pembelajaran yang diterapkan.
\end{abstract}

Kata Kunci: belajar; pembelajaran; teori constructivism

\section{Abstract}

The purpose of this writing is to find out how the learning process and evaluation it takes place during the teaching and learning process organized by educators, and learners not only as educational objects but also as subjects. This paper uses qualitative approaches and methods of literary study. In the world of education, learning can empower learners to be independent human beings and able to seize various opportunities in today's highly competitive life. This is when it is associated with spiritual pedagogy, the expected result as an evaluation material by an educator is when the learner instills the qualities of godhood in him so that he becomes a trusted caliph of God on earth by developing all the potential that exists in him. The success of the learning and evaluation process, will not be separated from the supporting components in the world of education, namely the components of vision, mission, goals, curriculum, teaching and learning process, educators, learners, management management, financing, infrastructure facilities, environment, communication networks and cooperation, as well as educational evaluation and basic learning strategies applied.

$\begin{array}{ll}\text { How to cite: } & \text { Salamah, U., Abdussalam, A., SyafeI, M., Firdaus, E., (2022) Pembelajaran Pedagogik Spiritual, Syntax } \\ & \text { Idea, 4(1), https://doi.org/ 10.36418/syntax-idea.v4i1.1691 } \\ \text { E-ISSN: } & \text { 2684-883X } \\ \text { Published by: } & \text { Ridwan Institute }\end{array}$


Keywords: learning; learning; Constructivism theory

Received: 2021-12-22; Accepted: 2022-01-05; Published: 2022-01-20

\section{Pendahuluan}

Pada dunia pendidikan, kegiatan belajar mengajar merupakan kegiatan yang paling pokok. Ini berarti bahwa berhasil atau tidaknya pencapaian tujuan pendidikan tergantung kepada bagaimana proses belajar mengajar itu dirancang dan diaplikasikan secara professional (Anwari et al., 2021).

Setiap kegiatan belajar mengajar ini, akan selalu melibatkan dua pelaku aktif, yaitu pendidik dan peserta didik. Pendidik sebagai pengajar, yang merupakan pencipta kondisi belajar peserta didik yang didesain secara sengaja, sistematis dan berkesinambungan. Sedangkan peserta didik adalah sebagai subjek pembelajaran yang merupakan pihak yang menikmati kondisi belajar yang diciptakan oleh seorang pendidik (Sulfemi, 2019).

Perpaduan dari kedua unsur manusiawi tersebut akan melahirkan interaksi yang bersifat edukatif jika memanfaatkan bahan ajar sebagai mediumnya. Pada proses belajar mengajar, antara pendidik dan peserta didik saling mempengaruhi satu sama lainnya dan memberikan masukan dari materi ajar yang sedang dipelajari. karena itu, maka hendaklah kegiatan belajar mengajar tersebut diusahakan merupakan aktivitas yang bisa menciptakan suasana yang hidup, sarat akan nilai-nilai dan senantiasa memiliki tujuan yang akan dicapai (Budiarti, 2019).

Kegiatan belajar mengajar, menempatkan peserta didik sebagai subjek pendidikan. Hal ini sejalan dengan pendapat Pupuh Fathurrohman dan M. Sobry Sutikno dalam bukunya "Strategi Belajar Mengajar melalui Penanaman Konsep Umum dan Konsep Islami" (Fathurrohman \& Sutikno, 2019). Beliau berpendapat bahwa pendidik dan peserta didik itu memiliki kedudukan setara, namun berbeda dari segi fungsi. Peserta didik merupakan subjek pembelajaran dan menjadi inti dari setiap kegiatan pendidikan. Tujuan pengajaran yang telah dirumuskan oleh pendidik tentu saja akan dapat tercapai jika peserta didik berusaha secara aktif untuk mencapainya. Keaktifan peserta didik disini tidak hanya dituntut dari segi fisiknya saja tetapi juga dari segi kejiwaannya. Hal ini diharapkan agar peserta didik dapat merasakan perubahan dalam dirinya (Firdianti, 2018).

Belajar juga diperintahkan dalam Islam, sebagaimana terdapat dalam ayat pertama yang diturunkan kepada Nabi Muhammad SAW. Karena belajar merupakan kewajiban utama dan sarana terbaik untuk mencerdaskan umat dan kebangkitan dunia, khususnya apabila ilmu yang dipelajari dibuktikan dengan amal perbuatan sehari-hari. Imam AlGhazali (Al-Abrasyi, 2003) menyatakan bahwa, "Meskipun seseorang itu membaca beratus ribu masalah ilmiah, kemudian mengajarkannya pula kepada orang lain, bila tidak diamalkannya sendiri, semua itu tidaklah ada faedahnya. Ilmu baru akan terasa manfaatnya ketika diamalkan oleh pemiliknya". Ini berarti bahwa, pemilik ilmu tersebut mendapatkan rahmat dari Allah SWT, ketika ilmu yang diperolehnya diamalkan dalam 
kehidupan sehari-hari disamping mengajarkannya kepada orang lain. Imam Al-Ghazali sangat tegas menyatakan bahwa tidak hanya mewajibkan belajar saja tetapi juga menegaskan pentingnya ilmu itu bila disertai dengan amal. Tidak cukup diamalkan saja, tetapi juga dibarengi dengan ikhlas dan jujur dalam segala amal perbuatannya.

Selain dari permasalahan diatas, dalam kegiatan belajar mengajar juga dihadapkan kepada ketelatenan pendidik dalam pengelolaan kelas. Hal ini sangat terkait dengan bagaimana seorang pendidik itu dapat menciptakan suasana kelas yang kondusif sehingga peserta didik menjadi bergairah dan nyaman belajar. Hasil akhirnya, demi kepentingan peserta didik dan demi keberhasilan belajar itu sendiri.

\section{Metode Penelitian}

Penelitian yang dilakukan menggunakan pendekatan kualitatif dengan metode studi literatur. hal ini karena di dunia Pendidikan, pembelajaran dapat memberdayakan peserta didik menjadi manusia yang memilki karakter mandiri serta mampu memiliki peluang yang cukup besar di zaman yang sekarang penuh dengan kompetitif yang cukup ketat.

\section{Hasil dan Pembahasan}

\section{A. Konsep Pembelajaran}

\section{Hakikat Pembelajaran}

Secara sederhana, pembelajaran itu dapat diartikan sebagai usaha dalam mempengaruhi emosi, intelektual dan spiritual seseorang agar mau belajar sesuai dengan kehendaknya sendiri. karena itu, dengan adanya pembelajaran tersebut maka diharapkan akan terjadinya proses pengembangan moral keagamaan, aktivitas, dan kreativitas peserta didik melalui berbagai aktivitas interaksi dan pengalaman yang didapat peserta didik selama kegiatan belajar. Dari paparan ini, tampak jelas bahwa pembelajaran lebih dittik beratkan kepada aktivitas peserta didik ketika kegiatan belajar mengajar berlangsung. Ada beberapa pengertian pembelajaran, diantaranya adalah:

1. Usaha membimbing peserta didik dan menciptakan lingkungan yang memungkinkan terjadinya proses belajar untuk belajar (Fakhrurrazi, 2018).

2. Suatu proses bantuan/ bimbingan yang telaten dengan memberdayakan sumber belajar agar terjadi aktivitas belajar secara mandiri untuk menemukan fakta dan makna sekaligus mengaktualisasikannya dalam kehidupan mu'allam sebagai khalifah (Okonofua et al., 2017).

3. Usaha untuk mencapai tujuan berupa kemampuan tertentu atau usaha untuk terciptanya situasi belajar sehingga yang belajar memperoleh atau meningkatkan kemampuannya (Jamaludin, 2021).

4. Seperangkat peristiwa yang diciptakan dan dirancang untuk mendorong, menggiatkan dan mendukung belajar siswa (Jamaludin, 2021).

5. Penciptaan sistem lingkungan yang memungkinkan terjadinya belajar. Penciptaan sistem lingkungan berarti menyediakan seperangkat peristiwa- 
kondisi lingkungan yang dapat merangsang anak untuk melakukan aktivitas belajar (Johar \& Hanum, 2016).

Pada beberapa pendapat di atas, maka dapatlah diambil suatu kesimpulan, bahwa pembelajaran itu adalah segala usaha atau bimbingan yang dilakukan oleh si pendidik agar dapat menciptakan suasana belajar yang kondusif bagi peserta didik sesuai dengan tujuan dari pembelajaran itu dilaksanakan. Pada hal ini, bagaimanapun peserta didik tidak hanya diberi ikan, melainkan juga diberikan alat dan cara menggunakannya untuk menangkap ikan, bahkan diberikan juga kemampuan untuk menciptakan alat untuk menangkap ikan tersebut.

Sebab dari karena itu, untuk mencapai itu semua yang telah dirumuskan oleh pendidik dalam tujuan pembelajaran yang akan dicapainya dalam proses belajar mengajar maka diharapkan setiap usaha membelajarkan peserta didik sudah pasti tidak akan terlepas dari kebutuhan akan persiapan yang matang, waktu yang memadai, sarana prasarana yang lengkap, dan sebagainya. Berbagai hal yang telah dikeluarkan terkait untuk kepentingan kegiatan pembelajaran tersebut tentu harus mendatangkan hasil yang maksimal dan tidak sia-sia.

Pembelajaran yang penulis bahas disini dibatasi hanya pada pembelajaran yang berlangsung di sekolah saja. Pembelajaran yang hanya dilakukan oleh guru sebagai pengajar dengan menggunakan perencanaan pelaksanaan pembelajaran dalam rangka pencapaian tujuan pendidikan/ pembelajaran. Pada penelitian ini, maka pembelajaran merupakan suatu kompetensi atau tugas seorang guru untuk melihat sejauh mana perubahan dari tingkah laku yang dialami peserta didiknya dari proses belajar mengajar tersebut (Suherman, 2018).

Belajar itu merupakan proses mental-intelektual. Terjadinya belajar (reaksi mental-intelektual) pada diri anak, memerlukan objek eksternal yang berupa peristiwa ataupun sistem lingkungan, yaitu serangkaian conditioning yang dapat merangsang terjadinya belajar pada diri anak. Pembelajaran itu terjadi ketika aktivitas guru yang berupa kegiatan penciptaan peristiwa atau sistem lingkungan, yang dimaksudkan agar mental-intelektual anak terdorong dan terangsang untuk melakukan aktivitas belajar. Jadi dalam hal ini, sangat dibutuhkan kreativitas seorang peserta didik dalam proses pembelajaran agar dapat terlaksana seefektif mungkin dan tujuan yang telah dirumuskan pun tercapat secara maksimal.

\section{B. Teori Constructivism dalam Pembelajaran}

Seiring dengan perkembangan zaman, maka teori Constructivism tentang pembelajaran menurut (Fakhrurrazi, 2018) ini merupakan proses aktif dari peserta didik untuk merekonstruksi makna dengan cara memahami teks, kegiatan dialog, pengalaman fisik, dan sebagainya. Belajar merupakan proses mengasimilasikan dan menghubungkan pengalaman atau bahan yang dipelajarinya dengan pengertian yang sudah dimiliki, sehingga pengertiannya menjadi berkembang. 
Beberapa bentuk pembelajaran yang sesuai dengan filsafat constructivism ini antara lain: diskusi, pengujian hasil penelitian sederhana, demonstrasi, peragaan prosedur ilmiah, dan kegiatan praktis lainnya yang memberikan peluang kepada peserta didik untuk mempertajam gagasannya.

Konstruktivisime merupakan proses pembelajaran yang menerangkan bagaimana pengetahuan disusun dalam diri manusia. Unsur-unsur konstruktivisme telah lama dipraktekkan dalam proses belajar dan pembelajaran baik di tingkat sekolah dasar, menengah, maupun universitas, meskipun belum jelas terlihat (Kristiyanto, 2019). Berdasarkan faham konstruktivisme, dalam proses belajar mengajar, guru tidak serta merta memindahkan pengetahuan kepada peserta didik dalam bentuk yang serba sempurna. Dengan kata lain, peserta didik harus membangun suatu pengetahuan itu berdasarkan pengalamannya masing-masing. Pembelajaran adalah hasil dari usaha peserta didik itu sendiri. Pola pembinaan ilmu pengetahuan di sekolah merupakan suatu skema, yaitu aktivitas mental yang digunakan oleh peserta didik sebagai bahan mentah bagi proses renungan dan pengabstrakan. Pikiran peserta didik tidak akan menghadapi kenyataan dalam bentuk yang terasing dalam lingkungan sekitar. Realita yang diketahui peserta didik adalah realita yang dia bina sendiri. Peserta didik sebenarnya telah mempunyai satu set idea dan pengalaman yang membentuk struktur kognitif terhadap lingkungan mereka. Untuk membantu peserta didik dalam membina konsep atau pengetahuan baru, guru harus memperkirakan struktur kognitif yang ada pada mereka. Apabila pengetahuan baru telah disesuaikan dan diserap untuk dijadikan sebagai pegangan kuat mereka, barulah penelitian baru tentang sesuatu bentuk ilmu pengetahuan dapat dibina. Penelitian terdahulu yang dilakukan oleh John Dewey menguatkan teori konstruktivisme ini dengan mengatakan bahwa pendidik yang cakap harus melaksanakan pengajaran dan pembelajaran sebagai proses menyusun atau membina pengalaman secara berkesinambungan. Beliau juga menekankan kepentingan keikutsertakan peserta didik di dalam setiap aktivitas pengajaran dan pembelajaran. Ditinjau perspektif epistemologi yang disarankan dalam konstruktivisme, maka fungsi guru akan berubah. Perubahan akan berlaku dalam teknik pengajaran dan pembelajaran, penilaian, penelitian dan cara melaksanakan kurikulum. Sebagai contoh, perspektif ini akan mengubah kaidah pengajaran dan pembelajaran yang menumpu kepada kemampuan peserta didik mencontoh dengan tepat apa saja yang disampaikan oleh guru, kepada kaidah pengajaran dan pembelajaran yang menumpu kepada kemampuan peserta didik dalam membina skema pengkonsepan berdasarkan pengalaman yang aktif. Ia juga akan mengubah tumpuan penelitian dari pembinaan model berdasarkan kaca mata guru kepada pembelajaran sesuatu konsep ditinjau dari kaca mata peserta didik. 


\section{Tujuan Belajar dan Pembelajaran}

Belajar itu tidak hanya berlangsung di sekolah saja, tetapi juga berlangsung dalam kehidupan sehari-hari peserta didik, baik itu di rumah, lingkungan masyarakat sekitar dan lain sebagainya. Belajar yang dialami oleh peserta didik merupakan suatu proses. Peserta didik mengalami proses mental dalam menghadapi bahan belajar yang dapat berbentuk berupa manusia, alam, hewan, tumbuh-tumbuhan, dan bahan lainnya yang telah terhimpun dalam bukubuku pelajaran atau sumber belajar lainnya.

Sebab dari hal itu, maka proses belajar yang dialami peserta didik berlangsung secara internal yang kompleks yang melibatkan ranah kognitif, afektif dan psikomotorik. Proses belajar yang mengaktualisasikan ranah-ranah tersebut tertuju pada penguasaan bahan pelajaran tertentu.

Sementara itu, pendidik dalam proses belajar tersebut tampak sebagai perilaku belajar karena sesuatu hal yang diberikan kepada peserta didik, baik berupa ilmu pengetahuan, keterampilan, pengalaman dan lain sebagainya. Hal ini berarti bahwa proses belajar dapat diamati oleh pendidik secara tidak langsung. Meskipun proses internal peserta didik tersebut tidak dapat diamati tetapi dapat dipahami oleh guru. Ini disebabkan proses belajar itu "tampak" lewat perilaku peserta didik. Perilaku belajar tersebut merupakan respons peserta didik terhadap tindak mengajar atau tindak pembelajaran dari guru yang merupakan sasaran yang dituju melalui belajar.

Adapun tujuan pembelajaran secara umum menurut pendapat (Abdussalam, 2017), adalah:

"Membina manusia yang mampu memberdayakan potensi diri (jasadiyahakliyah-ruhiyyah)-nya secara integratif dan memberdayakan lingkungan (masyarakat dan alam)-nya secara proporsional dalam rangka mengaktulisasikan dirinya sebagai khalifah Allah".

Dari tujuan tersebut, jelaslah bahwa pembelajaran itu lebih diarahkan kepada pengembangan potensi yang ada di dalam diri peserta didik itu sendiri sebagai penerapan dari kekhalifannya di muka bumi. Kewajiban belajar mengajar, merupakan salah satu pokok ajaran yang terkandung dalam al-Qur'an, yang menurut (Wahab, 2016) terdapat dalam QS Al-Ankabut (29): 19-20, yaitu sebagai berikut:

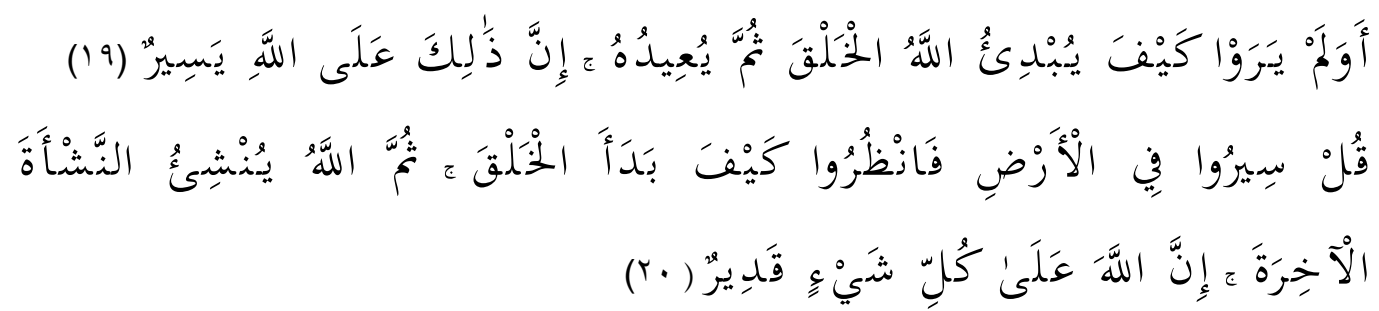


(19) Dan apakah mereka tidak memperhatikan bagaimana Allah menciptakan (manusia) dari permulaannya, kemudian mengulanginya (kembali). Sesungguhnya yang demikian itu adalah mudah bagi Allah.

(20) Katakanlah: "Berjalanlah di (muka) bumi, maka perhatikanlah bagaimana Allah menciptakan (manusia) dari permulaannya, kemudian Allah menjadikannya sekali lagi. Sesungguhnya Allah Maha Kuasa atas segala sesuatu.

Ayat di atas menjelaskan bahwa Allah mengarahkan kepada manusia agar melakukan riset tentang asal usul kehidupan yang kemudian riset tersebut dijadikan bukti beraneka ragamnya ciptaan Allah. Hal ini didapatkan ketika manusia melakukan perjalanan sehingga memperoleh suatu pelajaran dan pengetahuan dalam jiwanya yang menjadikannya sebagai manusia yang terdidik dan terbina, seperti ketika dia menemui orang-orang terkemuka sehingga memperoleh manfaat.

Tidak sampai disitu saja, manusia juga akan menemukan banyak pelajaran yang berharga baik melalui ciptaan Allah yang terhampar dan beraneka ragam maupun dari peninggalan-peninggalan lama yang masih tersisa puing-puingnya. Meskipun demikian perjuangan mencari ilmu pengetahuan merupakan tugas atau kewajiban bagi setiap Muslim baik laki-laki maupun wanita.

\section{Pembelajaran Pedagogik Spiritual}

Di dalam Islam, belajar dengan berbagai pengertiannya sebagaimana tersebut di atas mendapatkan perhatian dan sekaligus visi yang khas. Di dalam Islam terdapat sejumlah kegiatan yang menggunakan kemampuan kognitif (akal), afektif (perasaan), psikomotorik (perbuatan), fitrah serta berkaitan dengan kecakapan bakat, minat dan kecenderungan. Di dalam Islam dijumpai perintah berpikir (la allakum tatafakkarun), perintah menggunakan akal dalam melakukan penalaran (afa laa ta'qilun), perintah untuk melakukan pengamatan, dan observasi (afa laa yandzuru), perintah memahami secara mendalam (li yatafaqqahu), perintah merenungkan rahasia sesuatu (afalaa yadabbarun), perintah untuk mengerjakan sesuatu (i'malu ala makanatikum), perintah untuk mengetahui (li ta'lamu adada al-sinin), perintah untuk membaca (iqra'), perintah untuk menulis (allama bi al-qalam), perintah untuk melukis (nun wa alqalami wa maa yasturun), perintah untuk melakukan studi banding (awalam yasiru fi al-ardl), perintah untuk bersifat baik sangka (positive thinking-innama al-ma'lu bin niyat), perintah untuk mendemonstrasikan (shallu kama raitum muni ushali), perintah untuk menolong (wa ta'awanuu ala al-birri wa al-takwa), perintah untuk tidak hanya berkata melainkan mengerjakan (kabura maktan indallah antakulu mala taf'alun), perintah untuk meneliti setiap pekerjaan yang dilakukan (hasibu anfusakum qabla antuhasabu), dan sebagainya. Hal ini memerlukan proses pembelajaran yang dirancang secara sungguh-sungguh dan konseptual, sehingga benar-benar terarah dan mendapatkan hasil yang optimal. Semua kecakapan kejiwaan dan fitrah tersebut baru dapat menolong manusia, 
apabila diberdayakan sebaik-baiknya. Pemberdayaan ini memerlukan kegiatan belajar.

Namun demikian, konsep Islam tentang belajar tidak hanya berhenti pada tataran yang bersifat empiris, behavioristik, dan psiko analitis yang cenderung materialistis, sekalaristik dan hedonistik, melainkan harus dilanjutkan pada tataran visi teologis, sosiologis dan ekologis, sehingga belajar tersebut dapat dipertanggung jawabkan hasilnya dihadapan Tuhan, masyarakat, dan lingkungan alam yang lebih luas. Keharusan menempatkan kegiatan belajar dalam visi teologis misalnya, dapat dilihat dalam peintah Tuhan dalam surat al-Alaq yang memerintahkan membaca dalam arti yang seluas-luasnya yang dihubungkan dengan Tuhan (Iqra' bismirabbika=bacalah dengan menyebut nama Tuhan). Belajar dengan membaca berbagai ciptaan Tuhan: langit, bumi, manusia, binatang, tumbuhan, air, udara, bahan-bahan tambang, fenomena sosial dan sebagainya, harus dilihat sebagai ayat-ayat Allah. Dengan cara demikian, hasil belajar tersebut akan mengantarkan menjadi orang yang semakin dekat pada Tuhan. Hal ini sejalan pula dengan konsep orang yang berpengetahuan luas (ulama), yang dengan pengetahuannya yang luas itu semakin membawanya semakin patuh dan tunduk pada Tuhan sebagaimana ini diisyaratkan dalam surat al-Fathir ayat 27-29.

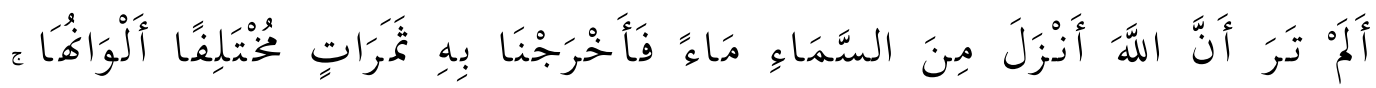

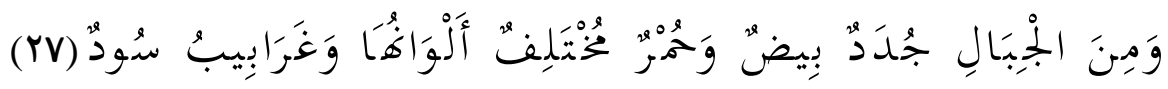

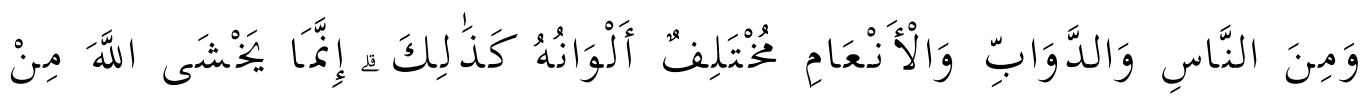

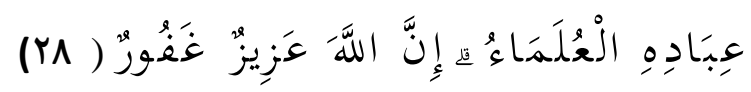

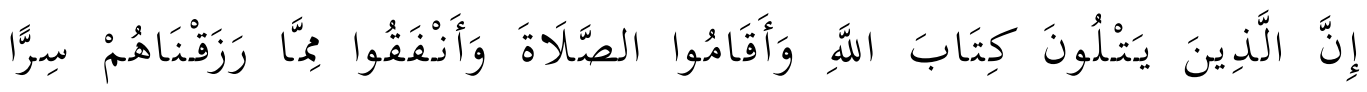

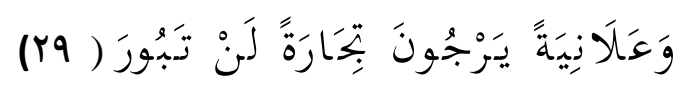

(27) Tidakkah kamu melihat bahwasanya Allah menurunkan hujan dari langit lalu Kami hasilkan dengan hujan itu buah-buahan yang beraneka macam jenisnya. Dan di antara gunung-gunung itu ada garis-garis putih dan merah yang beraneka macam warnanya dan ada (pula) yang hitam pekat.

(28) Dan demikian (pula) di antara manusia, binatang-binatang melata dan binatangbinatang ternak ada yang bermacam-macam warnanya (dan jenisnya). Sesungguhnya yang takut kepada Allah di antara hamba-hamba-Nya, hanyalah ulama. Sesungguhnya Allah Maha Perkasa lagi Maha Pengampun. 
(29) Sesungguhnya orang-orang yang selalu membaca kitab Allah dan mendirikan shalat dan menafkahkan sebahagian dari rezeki yang Kami anugerahkan kepada mereka dengan diam-diam dan terang-terangan, mereka itu mengharapkan perniagaan yang tidak akan merugi,

Selanjutnya, konsep belajar yang dikaitkan dengan visi tanggung jawab sosial dapat dipahami dari hadits Rasulullah SAW, yang menginformasikan bahwa di akhirat nanti setiap orang yang berilmu akan dimintakan pertanggung jawabannya tentang ilmu yang dimilikinya ( wa min ilmihi bima umila bihi=dan dengan ilmunya digunakan untuk apa), dan hadits nabi lainnya, yang mengatakan bahwa orang yang tidak mengamalkan ilmunya untuk kebaikan akan disiksa sebelum para penyembah berhala ( $f a$ alimun bi ilmihi lam ya'malam muadzabun min qalbi ubbadil watsan=orang alim yang tidak mengamalkan ilmu baik dengan mengajarkannya atau menerapkannya dalam kegiatan bekerja, maka ia akan disiksa sebelum para penyembah berhala).

Adapun konsep belajar yang dikaitkan dengan visi ekologis dapat dipahami dari kebijakan Tuhan yang mengangkat Nabi Adam untuk menjadi khalifah dengan memakmurkan dan mengolah alam raja, dengan terlebih dahulu diberikan pengetahuan oleh Tuhan, dengan melalui kegiatan pembelajaran sebagaimana diisyaratkan dalam ayat wa allama Adam al-asma aa kullaha (Allah mengajarkan Adam tentang berbagai nama Tuhan dan ayat-ayat yang ada di jagat raya).

Dengan visi belajar yang demikian itu, maka seorang muslim yang belajar, selain semakin tinggi dan mendalam ilmu, wawasan, keterampilan dan kecakapannya, juga akan semakin menjadi orang yang tawadlu (tunduk kepada Tuhan), tidak berani menggunakan ilmunya itu untuk hal-hal yang bertentangan dengan kehendak Allah, serta semakin meningkat kepeduliannya terhadap kesejahteraan masyarakat, dan kelestarian lingkungan.

Visi belajar di luar Islam ditujukan untuk mendapatkan ilmu, wawasan, keterampilan dan sebagainya, tanpa memberikan arahan untuk apa ilmu tersebut. Sedangkan Islam secara ajaran yang komprehensif, tidak hanya memotivasi dan mengarahkan tentang bagaimana cara mencari ilmu, melainkan juga mengarahkan tentang bagaimana menggunakan ilmu tersebut.

\section{Kesimpulan}

Dari penelitian yang telah dilakukan, ada beberapa hasil yang didapat yaitu: (1.) Pada hakikatnya pembelajaran itu dititik beratkan pada aktivitas peserta didik ketika kegiatan belajar mengajar berlangsung. (2.) Agar proses pembelajaran itu dapat mencapai tujuan yang telah dirumuskan oleh guru, maka diciptakanlah kondisi-kondisi yang dapat mendorong dan merangsang siswa untuk melakukan aktivitas belajar. (3.) Teori Constructivism tentang pembelajaran: Siswa diharapkan dapat mengasimilasikan dan menghubungkan pengalaman/ bahan yang dipelajarinya dengan pengertian yang 
sudah dimilikinya. (4.) Tujuan belajar dan pembelajaran adalah membina manusia yang mampu memberdayakan potensi diri (jasadiyah-akliyah-ruhiyyah)-nya secara integratif dan memberdayakan lingkungan (masyarakat dan alam)-nya secara proporsional dalam rangka mengaktualisasikan dirinya sebagai khalifah. (5.) Pembelajaran secara umum hanya menitik beratkan kepada proses belajar mengajar yang tampak atau yang dapat diamati oleh panca indera yaitu perubahan tingkah laku, sementara Islam lebih spesifik pada tataran teologis yaitu segala ilmu pengetahuan yang didapat dari hasil pembelajaran tersebut akan dipertanggung jawabkan di hadapan Tuhan, masyarakat dan lingkungan.

\section{BIBLIOGRAFI}

Abdussalam, Aam. (2017). Pembelajaran dalam Islam: Konsep Ta'lim dalam Alquran. Yogyakarta: Maghza.Google Scholar

Al-Abrasyi, M. '. (2003). Prinsip-Prinsip Dasar Pendidikan Islam. Bandung: Pustaka Setia.

Anwari, Ahmad Mufit, Kholik, Nur, S Pd I, M. S. I., Mainuddin, M. Pd I., Umami, Rita, Putri, Rahmawida, \& Rahayu, Rizqi. (2021). Strategi Pembelajaran: orientasi standar proses pendidikan. Edu Publisher. Google Scholar

Budiarti, Erna. (2019). Interaksi Edukatif Guru Dan Siswa Dalam Pembelajaran Pendidikan Agama Islam Di Sekolah Menengah Kejuruan Taruna Pekanbaru. Universitas Islam Negeri Sultan Syarif Kasim Riau. Google Scholar

Fakhrurrazi, Fakhrurrazi. (2018). Hakikat pembelajaran yang efektif. At-Tafkir, 11(1), 85-99. Google Scholar

Fathurrohman, Pupuh, \& Sutikno, M. Sobry. (2019). Strategi Belajar Mengajar Melalui Penanaman Konsep Umum \& Konsep Islami. Google Scholar

Firdianti, Arinda. (2018). Implementasi manajemen berbasis sekolah dalam meningkatkan prestasi belajar siswa. Gre Publishing. Google Scholar

Jamaludin, Ahmad. (2021). Perlindungan Hukum Anak Korban Kekerasan Seksual. JCIC: Jurnal CIC Lembaga Riset Dan Konsultan Sosial, 3(2), 1-10. Google Scholar

Johar, Rahmah, \& Hanum, Latifah. (2016). Strategi belajar mengajar. Deepublish. Google Scholar

Kristiyanto, Arif. (2019). Pembelajaran Sejarah Yang Berbasis Masalah Dalam Konteks Sosial Budaya Siswa. Ijtimaiya: Journal of Social Science Teaching, 3(2). Google Scholar 
Okonofua, Friday, Ogu, Rosemary, Agholor, Kingsley, Okike, Ola, Abdus-Salam, Rukiyat, Gana, Mohammed, Randawa, Abdullahi, Abe, Eghe, Durodola, Adetoye, \& Galadanci, Hadiza. (2017). Qualitative assessment of women's satisfaction with maternal health care in referral hospitals in Nigeria. Reproductive Health, 14(1), 18. Google Scholar

Suherman, Ayi. (2018). Kurikulum pembelajaran penjas. UPI Sumedang Press. Google Scholar

Sulfemi, Wahyu Bagja. (2019). Korelasi Kompetensi Pedagogik Guru dengan Prestasi Belajar Mata Pelajaran IPS Di SMP Muhammadiyah Pamijahan Kabupaten Bogor. Google Scholar

Wahab, R. (2016). Psikologi Belajar. Jakarta: PT RajaGrafindo Persada.

\section{Copyright holder:}

Umi Salamah, Aam Abdussalam, Makhmud SyafeI, Endis Firdaus (2021)

\section{First publication right:}

Syntax Idea

\section{This article is licensed under:}

